FESIEE

Fundación Emilio Soldevilla de la Investigacion y Desarrollo de la Economia de la Empresa

\section{Management Letters / Cuadernos de Gestión}

\author{
journal homepage: http://www.ehu.eus/cuadernosdegestion/revista/es/
}

ISSN: 1131-6837 / e-ISSN: 1988-2157

\title{
Why a strong work-life balance system is needed?
}

\section{¿Por qué es necesario un sistema de conciliación de la vida profesional y personal fuerte?}

\author{
Susana Pasamar \\ Universidad Pablo de Olavide. Sevilla (Spain)
}

* Corresponding author: Susana Pasamar. Universidad Pablo de Olavide. Carretera de Utrera Km 1,41013 Sevilla (Spain) - spasrey@upo.es-https://orcid.org/0000-0002-0462-3104

\section{A R T I C L E I N F O}

Received 14 February 2018, Accepted 16 September 2019

Available online 28 April 2020

DOI: $10.5295 / \mathrm{cdg} .180903 \mathrm{sp}$

JEL CODE: M500, M54

\begin{abstract}
A B S T R A C T
Purpose. This paper describes the concept of "strength of the work-life balance system" as a new and more advanced form of involvement in work-life issues, which lead to a stronger relationship with positive outcomes such as performance, commitment or satisfaction.

Design/methodology/approach. From a theoretical point of view, and following Bowen and Ostroff (2004; 2016)'s framework of strength, all the features of a strong work-life balance system are described. We define the characteristics that allow the work-life balance system to create strong situations in which clear messages are sent to employees about what appropriate behavior is.

Findings. Offering specific practices or specific types of support is not enough; a strong work-life balance system must also be in place. The strength of the system, which refers to the process, allows the firm to convey a consistent message about the content of the practices. Employees' motivation, attitudes and behaviors towards work-life balance are highly dependent on how they interpret the signals from employers about the work-life balance system designed but also implemented.

Practical implications. Future research and practitioners should pay more attention not only to design work life practices, but also to the implementation process in order not to fail in gaining all the positive outcomes related to work life balance, for employers and employees.

Originality/value. This paper is the first step in the exploration of the importance of the implementation process of a work-life balance system, for a better contribution to organization positive outcomes.
\end{abstract}

Keywords: Work-life balance, performance, implementation process.

\section{R E S U M E N}

Objetivo. Este trabajo describe el concepto de fortaleza del sistema de conciliación de la vida profesional y personal como una nueva y más avanzada forma de implicación de las empresas en temas de conciliación, lo que conduciría a una mayor relación con resultados positivos como resultados, compromiso o satisfacción. Diseño/metodología/enfoque. Desde un punto de vista teórico, y siguiendo el marco de fortaleza de los sistemas propuesto por Bowen y Ostroff $(2004 ; 2016)$, se describen todas las características de un sistema de conciliación de la vida profesional y personal fuerte.

Resultados. La oferta de prácticas específicas no es suficiente, se requiere un sistema de conciliación fuerte. La fortaleza del sistema, que se refiere al proceso, permite a la empresa enviar un mensaje consistente sobre el contenido de las prácticas. La motivación, actitudes y comportamientos de los empleados hacia la conciliación dependen en gran medida de cómo interpretan las señales que reciben de la empresa, según se haya implementado el sistema de conciliación.

Implicaciones prácticas. Tanto profesionales como futuras investigaciones deben prestar más atención al proceso de implementación y no solo al diseño de prácticas de conciliación, para no perder todos los posibles resultados positivos derivados de la conciliación tanto para empleados como para empresas.

Originalidad/valor. Este trabajo supone un primer paso para una mayor comprensión de la importancia del proceso de implementación de un sistema de conciliación de la vida profesional y personal, y para una mayor contribución a resultados positivos.

Palabras clave: Conciliación de la vida profesional y personal, resultados, proceso de implementación. 


\section{INTRODUCTION}

In recent years the literature has devoted a great deal of attention to work-life balance (WLB) practices and their diffusion in companies. The related positive outcomes and how they can help an organization become more effective and achieve a competitive advantage have been discussed in the context of demographic, societal and cultural changes over the last few decades, and may be even more important under challenging financial and economic conditions (Pasamar and Valle 2013; James 2014). Nevertheless, although there is a general assumption that the availability of WLB practices leads to positive organizational results through improved quality of life, satisfaction, commitment, productivity and performance, retaining and attracting highly qualified professionals (Scandura and Lankau 1997; Baral and Bhargava 2010), these effects are not automatic consequences.

Despite its recurrence as a research topic in recent times, little attention has been paid to the relationship between WLB measures and business performance (Perry-Smith and Blum 2000; Clifton and Shepard 2004; Beauregard and Henry 2009). Moreover, the question of how WLB programs contribute to firm performance remains unanswered, and this lack of clarity is one of the barriers to their implementation (De Luis et al. 2002; Cegarra-Leiva et al. 2012). The use of WLB policies has been linked to positive outcomes for employers and employees under the assumption of the "happy worker story" (Weeden 2005) and how these practices may enhance employees' job performance (Gajendram and Harrison 2007). Nevertheless, some studies have found that WLB programs have no effects (Konrad and Mangel 2000; Bloom et al. 2011), and others claim that the relationship between work-life initiatives and work-life conflict is not always so clear (Batt and Valcour 2003; Kelly et al. 2008). Moreover, the possibility of a flexibility stigma has been stated, as many employees report that they do not enjoy these benefits because they worry about negative career consequences (Williams et al. 2013).

Previous studies have called for further research on the relationship between Human Resource (HR) practices and organizational outcomes (Ferris et al. 1999; Bowen and Ostroff 2004). Specifically, WLB research has highlighted that the mere implementation of WLB practices is not enough to guarantee full company benefits (Cegarra-Leiva et al. 2012; Pasamar 2015) and organizations have to make an effort to promote a WLB supportive culture (McDonald et al. 2005). The existence of a supportive WLB culture is a fundamental mechanism through which these practices produce such an effect on organizational outcomes (Cegarra-Leiva et al. 2012).

Therefore, while a number of studies details what an appropriate set of WLB practices is (Goff et al. 1990; Goodstein 1995; Kopelman et al. 2006), it is also important to pay attention to the process of design and implementation of the WLB system (WLBS). Bowen and Ostroff (2004) proposed a framework for understanding how HR management practices can contribute to motivate employees to adopt desired attitudes and behaviors that eventually help achieve the organization's strategic goals, and the expected increase in firm performance. These authors discuss the importance of the climate as a channel to send signals to employees that help them to make the desired and appropriate responses and form a collective sense of what is expected of them.
They introduced the concept of "strength of the HRM system" and specify the metafeatures that lead to strong climates.

Following this framework, we describe the characteristics that allow WLBS to create strong situations in which clear messages are sent to employees about what appropriate behavior is, understanding that the success of the WLBS relies not only on the specific practices offered to the employees but in the implementation process and how controlling the strength of the systems companies make create strong climates that have an impact on attitudes and behaviors. Therefore, the propose of this paper is to describe the concept of "strength of the WLBS" as a new and more advanced form of involvement in WLB issues, which lead to a stronger relationship with positive outcomes such as performance, commitment or satisfaction.

\section{LITERATURE REVIEW: LINKING SYSTEMS STRENGTH AND WLB}

WLB practices are relevant because of their potential value for employers and employees. Implementing WLB benefits can enhance organizational results, but firms will fail in obtaining potential gains if employees are unaware of their existence or unable to use them (Prottas et al. 2007; Sánchez-Vidal et al. 2012).

HRM can be understood as communications from the employer to employee, and employees must have adequate and unambiguous information to function effectively and make accurate attributions about a situation. Through the lens of message-based persuasion and social influence literature, Bowen and Ostroff (2004) identified distinctiveness, consistency and consensus as the characteristics of HRM systems that would evolve into strong situations.

\subsection{Distinctiveness: Visibility, understandability, legitimacy of authority and relevance}

Distinctiveness refers to the features that make a system stand out in the environment, thereby attracting attention and sparking interest. There are four different system characteristics that can foster distinctiveness.

Visibility. Visibility of WLB practices refers to the degree of salience and observability of these practices, and is a prerequisite that enables employees to interpret them. The WLB benefits offered can create a sense of assurance for employees that their employers are concerned about their well-being, according to perceived organizational support theory (Baral and Bhargava 2010), but if WLB benefits are not transparent and communicated properly to the employees, the strength of the system will be affected.

Previous research pointed out that is not unusual than employees do not even know about the WLB offered by their companies (Lewis et al. 2000; Kodz et al. 2002). As Bowen and Ostroff proposed, visibility can be assessed by comparing a list of the practices deemed by the organization to be in place with the extent to which employees indicate they are in place (SanchezVidal et al. 2012). This gap between leaders and employees in their views of what practices are in place shows the weakness of the HRM system (Bowen and Ostroff 2016). 
Managers should clearly communicate their support for the values of family and personal aspects of life (Cegarra-Leiva et al. 2012). This explicit support would increase employees' visibility. Employees are not always aware that they can take advantage of WLB practices (Yeandle et al. 2002), and furthermore, in some cases they do not feel entitled to do so (Bud and Mumford 2006).

To overcome this visibility problem, work-life practices should be present throughout much of employees' daily work routines and activities. If the WLBS includes a wide range of practices that also affect a large number of employees, visibility is likely to be higher. If WLB practices are only offered to female parents, the firm is limiting its potential to achieve the benefits to business (Wise and Bond 2003). Understanding work-life conflict as "only a women's problem" is a dangerously divisive assumption (Lewis et al. 2003). While workers' preferred WLB arrangements may vary according to gender, life course or other circumstances, all employees value the opportunity to achieve a balance, not only young mothers (Kvande 2009; James 2011; Darcy et al. 2012).

For organizations that truly wish to foster WLB, a more effective approach would be to engage with all employees, not only women, by offering benefits that align with other desires, and promoting real diffusion among the workforce (Pasamar 2015). Shared meanings will not develop if the same practices are not perceived by or offered to most or all the employees (Bowen and Ostroff 2004).

Understandability. Obviously connected to visibility, understandability refers to unambiguous and easy to comprehend WLB practice contents. Organizational communication should aim to reduce ambiguity and vagueness (Bowen and Ostroff 2004). Employess' perceptions will be affected by factors such as previous experiences, values and expectations (Den Hartog et al. 2004). Employees must be able to understand how the WLB practice works, to avoid multiple interpretations and even misunderstandings. The recent case of Iberdrola provides a clear illustration. This Spanish company employs more than 9000 workers and recently introduced a working day with no lunch break. The process was met with some skepticism: employees, managers and trade unions all had their own fears and doubts about it. However, two years later, the company reports increased productivity, although managers recognize that the organizational culture has had to adapt to new circumstances (León 2014; Iberdrola 2019).

Obviously, lack of understanding is even more important when in affects managers, who play contradictory pivotal roles for the company. Managers act not just as agents responsible for profitability and growth, but also as victims of work-life conflict and, paradoxically, as important change agents in implementing policies designed to alleviate this conflict (Poelmans et al. 2003). Interestingly, although most HR managers perceive WLB benefits as incurring high economic costs, they admit to not knowing with any clarity the real economic costs and benefits involved in implementing these practices (Pasamar and Valle 2011).

Legitimacy of authority. According to Bowen and Ostroff (2004) this reflects the conceptual process that may lead "employees to consider submitting to performance expectations as formally sanctioned behaviors." The importance of any HR practice will rely on the top management's beliefs and values. As Kasper et al. (2005) state, "the way managers attribute sense to WLB will affect not only the way in which they 'walk the talk', but also how they implement organizational policies." Not surprisingly, recent studies highlight not only the lack of WLB for those in managerial positions, but also how relevant this message may be for the rest of the employees, presenting WLB as an impossible objective that is incompatible with advancements or promotion (Pasamar and Valle 2011). The use of WLB benefits may be inhibited not only by the presence of uncooperative supervisors, but also by fear of negative career consequences, which can occur when employees take up the WLB practices on offer (Breaugh and Frye 2008). Even when employees are fully informed of the WLB benefits available to them, many express reluctances to use them because they do not want to be perceived as less committed, cooperative or productive, or to have fewer chances of promotion (Beauregard and Henry 2009).

There are also cases in which employees do not feel entitled to take the legal benefits established by law, such as the numerous Spanish fathers who go back to work without taking the full days established by paternity leave legislation (15 days until 2019, at least eight weeks since then). These men find strong legitimacy for this behavior in the organizational culture, particularly the attitudes of their bosses. Precedents in taking paternity leave are an important influence in the decision of whether to take it or not. These employees may have a feeling of insecurity related to their jobs, and most of them are afraid of losing their positions (Romero-Balsas et al. 2012).

The WLBS is perceived as more authoritative when it has significant and visible support from top management. Legitimacy can be reflected in aspects such as resource allocation, or the involvement of the managers responsible of strategic decisions (Ostroff 1995). Investment in these practices, involvement or top managers' beliefs about the importance of WLB are some of the indicators or signals from top management that confirm the legitimacy or credibility of the system, and that are positively related to an increase of the level of use of WLB benefits (Pasamar 2015).

Obviously, communicator credibility is an essential component in attempts to attribute, persuade and influence (Bowen and Ostroff 2004). The attributes of implementation include supervisor support for use and universality of practice availability, and they will affect the degree to which WLB practices are seen by employees as fulfilling their needs (Ryan and Kossek 2008).

Relevance. The relevance of the WLBS refers to whether the situation is defined in such way that employees see it as related to achieving a specific goal. The most interesting aspect of relevance is the consideration of individuals' and employees' goals, and the alignment or congruence between these two types of goals (Bowen and Ostroff 2004). The situation must be defined in such a way that employees are willing to work toward goals that allow them to meet their own needs, but also the organizational aims. For instance, making WLB arrangements available can have a positive impact on institutionalized learning and the innovation environment within the firm, while employees experience improvements in their concentration, motivation, engagement, creativity, ability to interact and communicate with colleagues. This availability may even improve the firm's potential to attract and retain more a demographically diverse workforce, develop- 
ing networks of external contacts and hence its capacity to solve new problems (James 2014).

Studies by Mitsuhasi et al. (2000), Wright et al. (2001) and McLean (2006) have already shown that HR managers may find some practices very relevant to achieve organizational goals, while line managers may disagree, depending upon the situation in their business unit.

Finally, the relationship between legitimacy and relevance has been highlighted by previous studies (Bowen and Ostroff 2004). It appears that relevance alone can be enough to enhance distinctiveness. But when relevance is not strongly perceived, legitimacy plays a greater role that can compensate for this, with the result that such practices are perceived as distinctive (Taylor and Fiske 1991).

\subsection{Consistency: Instrumentality, Validity and Consistent WLB messages}

While distinctiveness focuses on the message and the communicator and how they may increase the probability that the WLB message will be encoded and understood uniformly across employees, it is clear that it is not enough on its own. Bowen and Ostroff (2004) propose also focusing on features that could guarantee consistent relationships over time, people and context, such as instrumentality, validity and consistent WLB messages.

Instrumentality. This involves establishing an explicit perceived cause-effect relationship that should ensure there are adequate incentives to foster the behavioral pattern desired (Bowen and Ostroff 2004). Specifically, it would be the degree to which WLBS positively contribute to motivation, commitment or any other desired effect in employees. A strong system would be one that succeeds in encouraging the desired behavior, reinforcing the intended performance (Delmotte et al. 2012). WLB practices are more effective when the firms need them (Konrad and Mangel 2000; Liu and Wang 2011). Firms will be likely to adopt WLB practices only if the promised outcomes are important to the effectiveness of the organizations' benefits plan and are likely to be achieved (Barringer and Milkovich 1998). But companies may also prioritize objectives that are more engaged with cost containment in line with their strategic goals and the context in which they are operating (Pasamar and Valle 2015).

Validity. The validity of WLBS is very important in making attributions. WLB practices must show consistency between what they claim to do and what they really do. When employees are told about WLB benefits and their conditions and effects and the reality differ from their expectations, they are receiving a contradictory message. The practices must not only sound good in theory, but function in practice (Delmotte et al. 2012). Managers may perceive that what they were asked to achieve in the business may often be incompatible with formal work-life policies (Wise and Bond 2003). Despite all the positive outcomes related to $\mathrm{WLB}$, and so many workers struggling to integrate often conflicting life roles, WLB programs are still under-utilized (Kossek et al. 2011). Employees may receive mixed messages if organizations announce a WLB benefits package while expecting behaviors that are incompatible with this balance: meetings outside normal working hours, reductions in working hours to accommodate time for personal life but with the same workload, the expectation of continuous and uninterrupted availability because of new technologies, and so on. If contradictions appear, employees are left to develop their own interpretations, and uniformity is lost.

Consistent WLB messages. Employees want constancy, and when it is lacking negative consequences can arise such as intense cognitive dissonance (Siehl 1985). Bowen and Ostroff proposed three types of required consistency that could apply to WLB systems. The first dimension refers to what senior managers say are the organization's goals and what employees actually conclude they are, based on their own perceptions. The inconsistency here refers to the espoused and inferred values and may be affected by miscommunication and mistrust (Martin and Siehl 1983). The lack of consistency may lead to misunderstanding and even employees' lack of satisfaction (Kepes and Delery 2007). In that sense, organizations should make an effort to send a clear and unique message about WLB, shaking off employees' fears about negative consequences. Managers' expectations for their employees to work long hour prioritizing work over personal life, technological advancements that make employees to be always available or the perceive insecurity in the labour market due to the economic crisis (Hyman et al. 2003) may play against this consistency.

The second requirement is internal consistency among WLB practices themselves. They should all pursue the same goals and should be designed to complement each another and fit together to create a whole so as to achieve this internal consistency (Bowen and Ostroff 2004). The lack of planning in some companies may explain this inconsistency, where WLB practices have been offered in response to requests from or needs of some groups of employees without an overall plan to integrate all the practices, and more importantly, to link them to other HR practices. Promotions, retribution, training and the possibility of career development may be integrated in the WLBS. If contradictions appear among these practices or there is a possibility of being penalized for having used WLB arrangements, the message workers receive is that organizations do not want them to take part in WLB programs (Brandth and Kvande 2002; McDonald et al. 2007).

The third type of consistency is related to the stability of practices in time (Bowen and Ostroff 2004). In this sense, the novelty of WLBS goes against them. The sense of agreement is stronger in organizations where practices have remained stable across time. Employees' behavior and its consequences are more predictable, and they are positive about what they can expect from the organization and what is expected of them.

\subsection{Consensus: Agreement among Decision Makers and Fairness}

Consistency and consensus are distinct but interrelated. When individuals experience consistency, consensus is more likely to be achieved, and vice versa. Consensus is the result of agreement among employees about the effects of WLBS. Therefore, Bowen and Ostroff (2004) suggested analyzing the degree of agreement among principal decision makers, and the fairness of the system.

Agreement among principal WLB decision makers. Agreement among the message senders would increase consensus among employees. In WLBS the difficulty may lie in identify- 
ing the decision makers: are they top managers, HR managers, supervisors, or others? When individuals perceive strong agreement among the message senders about the message, they are more likely to reach a consensus (Fiske and Taylor 1991).

When top management, HR manager and line supervisors agree on the way employees should be managed and clearly share the same vision, there is an increased likelihood of successful strategy implementation and a positive impact on firm performance (Delmotte et al. 2012).

Connecting this perception of agreement to distinctiveness, we propose that when all the WLB decision makers agree on the message, the visibility of the system will also be higher. When supervisors, HR managers and top managers interact, the formulation and implementation of WLBS clearly sends an agreed message, and also enhances the sense of legitimacy of authority.

Where there is disagreement among WLB decision makers, the message will be less visible, relevant and consistent. Therefore, employees would experience different cause-effect relationships, and the WLBS it would be perceived as weaker. All the organizational efforts to adopt, design, and implement WLB policies may eventually converge into single, discretionary decisions by supervisors on whether or not to 'allow' these policies (Poelmans and Beham 2008). Controlling the agreement among WLB decision makers is essential to achieve workers' perception of the strength of the WLBS.

Fairness. Fairness of the WLBS refers to the employees' perception of whether the system complies with distributive, procedural and interactional justice. A fair WLBS is more likely to be accepted by employees.

The distribution of WLB benefits may be perceived as fair by employees (distribution justice). In that sense, WLBS have to be carefully designed to avoid feelings of unfairness among employees, such as the belief that benefits are only aimed at mothers, or for taking care of younger children. Moreover, in the case of WLB benefits that HR department or line managers have to approve, impartiality is essential and any preferential treatment for closer employees must be avoided at all costs (procedural justice, Delmotte et al. 2012). Employees' perceptions of fairness in the WLB decision process, demonstrations of honest concern for the employees, and the provision of full information about the decision criteria and process may help avoid negative outcomes (Poelmans and Beham 2008). Employees were found to perceive even negative work outcomes as fair when clear and reliable information was provided to justify these outcomes or when high levels of interpersonal justice were displayed (Greenberg 1996; Cropanzano and Greenberg 1997). Literature also draws attention to the possibility of higher work load and coordination problems and the resulting sense of unfairness for coworkers (Carrasquer and Martin 2005).

Organizations that manage to handle the distinctiveness, consistency and consensus of their WLBS can enhance their performance because of the strength of WLBS (Table 1). In these companies the shared meanings in promoting collective responses would be consistent with the organizational goals.

As a result, it is suggested that the strength of the WLBS will lead not only to a better implementation of WL practices, but also to the achievement of positive outcomes, included perfor- mance. As it has been stated, a strong WLBS would promote positive attitudes, which have the capacity to predict organizational behavior.

Table 1

Theoretical WLBS model

\section{Distintiveness}

\section{Visibility}

Are WLB practices transparent and communicated properly to the employees?

\section{Understability}

Do employees understand how the WLB practices work to avoid multiple interpretations and even misunderstandings?

\section{Legitimacy of Authority}

Do employees perceive that their managers support these practices?

\section{Relevance}

Are WLB practices aligned with the organizational goals?

\section{Consistency}

\section{Instrumentality}

Is the relationship between WLB practices and motivation, commitment, performance or other desired effect on employees explicit?

\section{Validity}

WLB practices must show no contraction between what they claim to do and what they really do.

\section{Consistent messages}

Managers' expectations for their employees to work long hour prioritizing work over personal life may play against this consistency

\section{Consensus}

\section{Agreement}

Is there agreement among top managers, HR managers, supervisors, or other manager around WLB issues?

\section{Fairness}

Do employees perceive distributive, procedural and interactional justice around WLBS?

\section{Source: Table created by the author}

Previous research have observed the relationship between WLB benefits and different outcomes such as increases in perceived organizational support (Kopelman et al. 2006), productivity (Perry-Smith and Blum 2000; Clifton and Shepard 2004), innovation (James 2014), rises in price share (Arthur 2003), commitment and job satisfaction (Scandura and Lankau 1997) or career satisfaction (Lee et al. 2002), and decreases in negative elements for organizations such as tardiness, absenteeism and turnover (Christensen and Staines 1990; Dalton and Mesch 1991). These empirical findings support the idea of the "happy worker story" (Weeden 2005) under the assumption that those employees who enjoy a better WLB avoid all the negative consequences related to work-life conflict (Carlson et al. 2010). Moreover, social exchange theory proposes that employees feel obligated to reciprocate when they treated kindly and supportively (Blau 1964), what again lead us to the relevance of the message that a company convey to their employees through the HR Man- 
agement system. The underutilization of WLB benefits is still a common issue that can challenge all the possible outcomes for employees and organizations (Budd and Mumford 2006; Pasamar 2015). While some organizations keep myopic in terms of addressing the needs and aspirations of employees (Eikhof et al. 2007) the positive effects of WLB benefits will be lost (Kossek et al. 2011).

For these reasons, it can be argued that the strength of the WLBS is related to a broader diffusion of WLB benefits, which would involve the real use of these practices and not only the mere offer, as the WLBS would be better understood and accepted. This strength would also lead to positive outcomes for organizations and employees, as the firm would convey a consistent and clear message about WLB and employees would interpret those signals. Employees' motivation, attitudes and behaviors towards WLB are highly dependent on how they interpret the signals from employers, and consequently a strong WLBS would be related to positive outcomes for workers and organizations (See Figure 1).

Proposition 1. The level of strength of the WLBS will be positively related to the use of WL benefits.

Proposition 2. The level of strength of the WLBS will be positively related to positive outcomes for employees, such as increases in satisfaction and decreases in work-life conflict.

Proposition 3. The level of strength of the WLBS will be positively related to positive outcomes for employers, such as increases in performance, commitment, creativity and decrease in absenteeism and intention to quit.

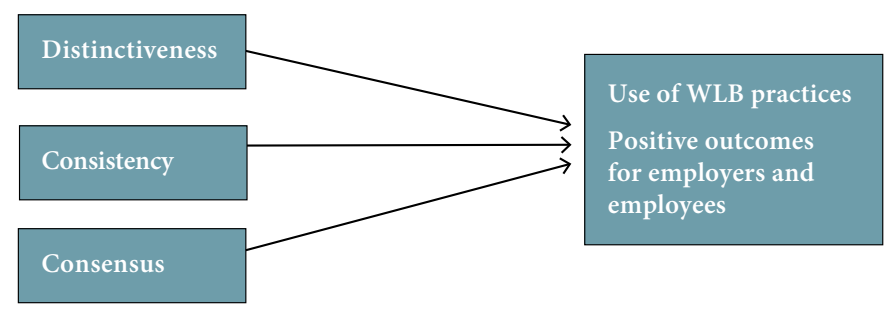

Figure 1

Relationships between the Strength of WLBS and the Use of Practices and Outcomes

Source: Figure created by the author

\section{CONCLUSIONS}

HR practices can help organizations build an organizational social structure that can increase flexibility and efficiency (Evans and Davis 2005) but the implementation of designed strategies can fail because of employees' perceptions about the HR management system. These practices seek to increase organizational performance by affecting employees' motivation, attitudes and behaviors, which are highly dependent on how employees interpret the signals from HR departments (García-Carbonell et al. 2014). Specifically, WLB practices may help firms send a strong message to their current and potential employees about how the organization values their employees and the contributions they make (Perry-Smith and Blum 2000).
A strong WLBS increases a generalized norm of reciprocity between organizations and employees. As long as WLBS remain optional, not mandatory, firms that make these practices available may be highly valued, because their decision to offer them is voluntary and expresses their appreciation of their employees (Roehling et al. 2001; Rhoades and Eisenberger 2002). Once the norm of reciprocity is created by WLBS, the employees will perceive their obligation and will have increased motivation to work, intention to remain with the organization, cooperation and trust (Rhoades and Eisenberger 2002; Evans and Davis 2005). Furthermore, according to Pfeffer's (1981) symbolic action perspective, when organizations offer WLB benefits they send out signals to employees that allow them to draw conclusions about their values and philosophies (Waters and Bardoel 2006).

Offering specific practices or specific types of support is not enough; there needs to be a strong WLBS in place. The strength of the system, which refers to the process, allows the firm to convey a consistent message about the content of the WLB practices. A strong WLB system would be a high level construct that enables organization to send unambiguous messages about the culture, climate, priorities, and values related to WLB. According to Bowen and Ostroff $(2004 ; 2016)$ integrated content and process will be more effective in attaining the intended behaviors, which WLB studies should take into account in order to try to explain the connection between WLB benefits and organizational performance and achieve the expected win-win situation for employees and employers (Pasamar 2015). A strong WLBS would convey a clear message to the employees and would create strong climates that have an impact on attitudes and behaviors. WLB practices would be understood and accepted, and their use would be also increased.

This study holds important implications for practitioners, who are currently facing important pressures to increase performance, while manage limited resources and meet employees' expectations regarding their development and careers (De Haw and De Vos 2010). Organizations should focus on practical strategies directed toward communication, moreover when they have younger workers (Real et al. 2010) and limited resources. So far, most companies have limited their offer of WLB practices to women with caring responsibilities, forgetting other employees (Pasamar 2015). Workers would respond to that organizational message with a limited use of practices, which eventually would mean the lack of positive outcomes for employer and employees.

One of the main limitations of this study is that only tackle the phenomenon from a theoretical point of view. Moreover, it would be debatable how far the implementation process should be generalizable to every context in order to attain the strength of the WLB system. In the future, practitioners and researchers should follow the theoretical SWLB system for a better result in the implementation. Future studies should consider empirically how the implantation process of WLBS may affect the achievement of all the positive outcomes for employers and employees.

The analysis of all the features of a strong system is vital. Specifically, the communication during the implementation of WLB systems is very relevant but has been neglected in previous research. Practitioners should take care of the message they convey 
when they offer WLB benefit. Not only the practices are relevant, but also how they are offered, to whom, or what are the managers' attitudes and expectations. In summary, the distinctiveness, the consistency and the consensus around the WLB system will determine its effectiveness. Replication of this research including different case studies may help to shed additional light onto this topic.

\section{REFERENCES}

Arthur, M.M., 2003. Share Price Reactions to Work-Family Initiatives. Academy of Management Journal, 46, 497-505.

Baral, R. and Bhargava, S., 2010. Work-family enrichment as a mediator between organizational interventions for work-life balance and job outcomes. Journal of Managerial Psychology, 25(3), 274-300.

Bardoel, E.A., 2003. The provision of formal and informal work-family practices: The relative importance of institutional and resource dependent explanations versus managerial explanations. Women in Management Review, 18(1/2), 7-21

Barringer, M. and Milkovich, G., 1998. A Theoretical Exploration of the Adoption and Design of Flexible Benefit Plans: A Case of Human Resource Innovation. Academy of Management Review, 23 , 305-324.

Batt, R. and Valcour, P.M., 2003. Human resources practices as predictors of work-family outcomes and employee turnover. Industrial relations, 42(2), 189-220

Beauregard, T. A. and Henry, L.C., 2009. Making the link between work-life balance practices and organizational performance. $\mathrm{Hu}$ man Resource Management Review, 19(1), 9-22.

Blau, Peter M., (1964). Exchange and Power in Social Life. Transaction. New York: Wiley.

Bloom, N., Kretschmer, T. and Van Reenen, J., 2011. Are family-friendly workplace practices a valuable firm resource? Strategic Management Journal. 32(4), 343-367

Bowen, D. and Ostroff, C., 2004. Understanding HRM-firm performance linkages: the role of the 'strength' of the HRM. The Academy of Management Review, 29(2), 203-221.

Bowen, D. and Ostroff, C., 2016. Reflections on the 2014 Decade Award: Is There Strength in the Construct of HR System Strength? Academy of Management Review, 41(2), 196-214.

Brandt, B. and Kvande, E., 2002. Reflexive fathers: Negotiating Parental Leave and Working Life. Gender, Work and Organization, 9(2), 186-203.

Breaugh, J. A., and Frye, N. K., 2008. Work-family conflict: The importance of family-friendly employment practices and family-supportive supervisors. Journal of Business and Psychology, 22(4), 345-353

Budd, J.W. and Mumford, K.A., 2006. Family-friendly work practices in Britain: availability and perceived accessibility. Human Resource Management, 45(1), 23-42

Carrasquer, P. and Martín, A., 2005. La política de conciliación de la vida laboral y familiar en la negociación colectiva. Un aspecto de la estrategia europea de empleo. Cuadernos de relaciones laborales, 23,1, 131-150

Carlson, D. S., Grzywacz, J. G. and Kacmar, K. M., 2010. The relationship of schedule flexibility and outcomes via the work-family interface. Journal of Managerial Psychology, 25(4), 330-355. https://doi. org/10.1108/02683941011035278

Cegarra-Leiva, D., Sánchez-Vidal, M. E. and Cegarra-Navarro, J., 2012. Understanding the link between work life balance practices and organisational outcomes in SMEs. Personnel Review, 41(3), 359-379

Cegarra-Navarro, J. G., Sánchez-Vidal, M.E. and Cegarra-Leiva, D. 2016. Linking Unlearning with Work-Life Balance: An Initial Empirical Investigation into SMEs. Journal of Small Business Management, 54(1), 373-391
Clifton, T.J. and Shepard, E., 2004. Work and family programs and productivity: Estimates applying a production function model. International Journal of Manpower, 25 (7/8), 714-728.

Christensen, K.E., and Staines, G., 1990. Flextime: A Viable Solution to Work/Family Conflict? Journal of Family Issues, 4, 455-477.

Cropanzano, R. and Greenberg, J., 1997. Progress in Organizational Justice: Tunnelling Through The Maze. In Cooper, C.L. and Robertson, I.T. (Eds.) International Review of Industrial and Organizational Psychology, vol. 12, 243-298. Chichester: Wiley.

Dalton, D.R., and Mesch, D.J., 1991. On the Extent and Reduction of Avoidable Absenteeism: An Assessment of Absence Policy Provisions. Journal of Applied Psychology, 76, 810-817.

Darcy, C., McCarthy, A., Hill, J. and Grady, G., 2012. Work-life balance: One size fits all? An exploratory analysis of the differential effects of career stage. European Management Journal, 30(2), 111120.

De Hauw, S. and De Vos, A., 2010. Millenials' Carreer Perspective and Psycologycal contract expetactions: Does the recesión lead to lowered expectations? Journal of Business Psycology, 25, 293-302

Delmotte, J., De Winne, S. and Sels, L., 2012. Toward an assessment of perceived HRM system strength: scale development and validation. The International Journal of Human Resource Management, 23(7), 1481-1506.

De Luis, M.P., Martínez, Á., Pérez, M. and Vela, M.J., 2002. La flexibilidad de la empresa y la conciliación de la vida laboral y familiar, Boletín Económico del ICE, 2741, 37-50.

Den Hartog, D.N., Boselie, P. and Paauwe, J., 2004. Performance management. Amodel and research agenda. Applied Psycologue, 53(4), 556-569

Eikhof, D.R.; Warhurst, C. and Haunschild, A., 2007. Introduction: What work? What life? What balance? Critical reflections on the worklife balance debate. Employee Relations, 29(4), 325-333, https://doi. org/10.1108/01425450710839452

Evans, W.A., 1994. Approaches to intelligent information retrieval. Information processing and management, 7 (2), 147-168.

Evans, W., R., and Davis, W.D., 2005. High-performance work systems and organizational performance: The mediating role of internal social structure. Journal of Management, 31, 758-775.

Ferris, G. R., Hochwarter, W. A., Buckley, M. R., Harrell-Cook, G. and Frink, D. D., 1999. Human resource management: Some new directions. Journal of Management, 25, 385-415.

Gajendran, R. S. and Harrison, D. A., 2007. The good, the bad, and the unknown about telecommuting: Meta-analysis of psychological mediators and individual consequences. Journal of Applied Psychology, 92(6), 1524-1541.

García Carbonell, N., Martín-Alcazar, F. and Sánchez Gardey, G., 2014. El papel moderador de la percepción del sistema de dirección de recursos humanos y su influencia en los resultados organizativos. Revista Europea de Dirección y Economía de la Empresa, 23, $137-146$

Goff, S.J., Mount, M.K. and Jamison, R.L., 1990. Employer supported child care, work-family conflict, and absenteeism: a field study. Personnel Psychology, 43(4), 793-810.

Goodstein, J., 1995. Employer involvement in eldercare: An organizational adaptation. Academy of Management Journal, 38(6), 16571671.

Greenberg J., 1996. The quest for justice on the job: Essays and experiments. Thousand Oaks, CA: Sage.

Hyman, J., Baldry, C. Scholarios, D. and Bunzel, D., 2003. Work-life imbalance in call centres and software development. British Journal of Industrial Relations, 41(2), 215-239

Iberdrola, 2019. https://www.iberdrola.com/personas-iberdrola/conciliacion 
James, A., 2011. Work-life (im)'balance' and its consequences for everyday learning and innovation in the New Economy: evidence from the Irish IT sector. Gender, Place and Culture: A Journal of Feminist Geography, 18(5), 655-684.

James, A., 2014. Work-life 'balance', recession and the gendered limits to learning and innovation (or, why it pays employers to care). Gender, Work and Organization, 21(3), 273-294.

Kasper, H., Meyer, M. and Schmidt, A., 2005. Managers dealing with work-family-conflict: an explorative analysis. Journal of Managerial Psychology, 20(5), 440-461.

Kelly, E. L., Kossek, E. E., Hammer, L. B., Durham, M., Bray, J., Chermack, K. and Murphy, L. A., 2008. Getting There from Here: Research on the Effects of Work-Family Initiatives on Work-Family Conflict and Business Outcomes. The Academy Of Management Annals, 2(7), 305-339.

Kepes, S., and Delery, J. E., 2007. HRM systems and the problem of internal fit. In P. Boxall. J. Purcell, and P. M. Wright (Eds.), The Oxford handbook of human resource management. Oxford University Press.

Kodz, J., Harper, H. and Dench, S., 2002. Work-life balance: Beyond the rhetoric. Institute for Employment Studies Report 384. London: IES.

Konrad, A. M. and Mangel, R., 2000. The impact of work-life programs on firm productivity. Strategic Management Journal, 21(12), 12251237.

Kopelman, R., Prottas, D. J., Thompson, C. A. and Jahn, E.W., 2006 A Multilevel Examination of Work-Life Practices: Is More Always Better? Journal of Managerial Issues, 18(2), 232-253,

Kossek, E. E., Baltes, B. B. and Matthews, R. A., 2011. How work-family research can finally have an impact in organizations. Industrial and Organizational Psychology: Perspectives on Science and Practice, 4, 352-369.

Kossek, E., Pichler, S., Bodner, T. and Hammer, L., 2011. Workplace social support and work-family conflict: a meta-analysis clarifying the influence of general and work-family specific supervisor and organizational support. Personnel Psychology, 64(2), 289-313.

Kvande, E., 2009. Work-life balance for fathers in globalized knowledge work. Some insights from the Norwegian context. Gender, work and organization, 16(1), 58-72

Lee, M. D., MacDermid, S., Williams, M., Buck, M. and Leiba-O'Sullivan, S., 2002. Contextual factors in the success of reduced-load work arrangements among managers and professionals. Human Resource Management, 41, 209-223.

León, P., 2014. La felicidad de trabajar de ocho a tres. http://politica.elpais. com/politica/2014/12/26/actualidad/1419616033_794119.html.

Lewis, S., Kagan, C. and Heaton, P., 2000. Managing work-family diversity for parents of disabled children: beyond policy to practice and partnership. Personnel Review, 29(3), 417-430.

Lewis, S., Rapaport, R. and Gambles, R., 2003. Reflections on the integration of paid work with the rest of the life. Journal of Managerial Psychology. 18(8), 824-841

Liu, N. and Wang C., 2011. Searching for a balance: work-family practices, work-team design, and organizational performance. International Journal of Human Resource Management, 22(10), 2071-2085

Martin, J. and Siehl, C. J., 1983. Organizational customer and counterculture: An uneasy symbiosis. Organizational Dynamics, 12(2), 5264.

McDonald, P., Brown, K. and Bradley, L., 2005. Explanations for the provision-utilisation gap in work-life policy. Women in Management Review, 20(1), 37-55.

McDonald, P., Pini, B. and Bradley, L., 2007. Freedom or fallout in local government? How work-life culture impacts employees using flexible work practices. International Journal of Human Resource Management, 18, 602-622
McLean, M., 2006. Evaluating the Importance and Performance of the Human Resources Function: An Examination of a Medium Sized Scottish Retailer. Journal of Retailing and Consumer Services, 13, 143-156.

Mitsuhasi, H., Park, H.J., Wright, P.M. and Chua, R.S., 2000. Line and HR Executives' Receptions of HR Effectiveness in Firms in the People's Republic of China. The International Journal of Human Resource Management, 11, 197-216.

Ostroff, C., 1995. SHRM/CCH Survey. Human Resources management: Ideas and Trend in Personnel. Chicago: Commerce Clearing House.

Pasamar, S., 2015, Availability and use of Work-life benefits. What's in between? Personnel Review 44(6), 949-969

Pasamar, S. and Valle, R., 2013. Work-life balance under challenging financial and economic conditions. International Journal of Manpower, 34(8), 961-974

Pasamar, S. and Valle, R., 2011. Conciliación de la vida profesional-personal en empresas españolas: ¿mito o realidad? Universia Business Review, 29, 14-31

Pasamar, S. and Valle, R., 2015. Antecedents of work-life involvement in work-life issues: Institutional pressures, efficiency gains or both? The International Journal of Human Resource Management, 26(8), 1130-1151.

Perry-Smith, J. and Blum, T., 2000. Work-Family Human Resource Bundles and Perceived Organizational Performance. Academy of Management Journal, 43(6), 1107-1117.

Pfeffer, J., 1981. Management as symbolic action: The creation and maintenance of organizational paradigms. In L. L. Cummings \& B. M. Staw (Eds.), Research in organizational behavior, 3, 1-52. Greenwich, CT: JAI Press.

Poelmans, S. and Beham, B., 2008. The moment of truth: Conceptualizing managerial work-life policy allowance decisions. Journal of occupational and organizational psychology, 81(3), 393-410.

Poelmans, S., Chinchilla, N. and Cardona, P., 2003. The adoption of family-friendly HRM policies: Competing for scarce resources in the labour market. International Journal of Manpower, 24(2), 128-147.

Prottas, D.J., Thompson, C.A., Kopelman, R.E. and Jahn, E.W., 2007. Work-Family Programs: Factors Affecting Employee Knowledge and Accuracy. Personnel Review, 36(2), 163-189

Real, K., Mitnik, A.D. and Maloney, W.F., 2010. More similar than different: Millenials in the U.S. Building Trades. Journal of Business Psycology, 25, 303-313

Rhoades, L. and Eisenberger, R., 2002. Perceived Organizational Support: A Review of the Literature. Journal of Applied Psychology, 87, 698-714.

Roehling, P.V., Roehling, M.V. and Moen, P., 2001. The Relationship between Work-life Policies and Practices and Employee Loyalty: A Life Course Perspective. Journal of Family and Economic Issues, 22, 141-170

Romero-Balsas, P., Muntanyola-Saura, D. and Rogero-García, J., 2012. Decision Making Factors in Paternity and Parental Leaves: Why Spanish Fathers Take Time off Work? Gender, work and organization, 20(6), 678-691

Ryan, A.M. and Kossek, E.E., 2008. Work-life policy implementation: Breaking down or creating barriers to inclusiveness? Human Resource Management, 47, 295-310.

Sánchez-Vidal, M.E., Cegarra-Leiva, D. and Cegarra-Navarra, J.G., 2012. "between managers' and employees' perceptions of work-life balance. The International Journal of Human Resource Management, 23(4), 645-661

Scandura, T. and Lankau, M.J., 1997. Relationships of Gender, Family Responsibility and Flexible Work Hours to Organizational Commitment and Job Satisfaction. Journal of Organizational Behavior, $18,377-391$ 
Siehl, C. J., 1985. After the founder: An opportunity to manage culture. In P. Frost, L. Moore, M. Louis, C. Lundberg, \& J. Martin (Eds.), Organizational culture: 125-140. Beverly Hills, CA: Sage.

Taylor, S. E. and Fiske, S. T., 1991. Social cognition. Nueva York: McGrawHill

Waters, M. A. and Bardoel, E. A., 2006. Work-family policies in the context of higher education: Useful or symbolic? Asia Pacific Journal of Human Resources, 44(1), 67-82

Weeden, K.A., 2005. Is there a flexiglass ceiling? Flexible work arrangements and wages in the United States. Social Science Research, 34, 454-482

Williams, J. C., Blair-Loy, M. and Berdahl, J., 2013. Cultural schemas, social class, and the flexibility stigma. Journal of Social Issues, 69 (2), 209-234.
Wise, S. and Bond, S., 2003. Work-life policy: Does it do exactly what it says on the tin? Women in Management Review, 18(1/2), 20-31

Wright, P.M., McMahan, G.C., Snell, S.A. and Gerhart, B., 2001. Comparing Line and HR Executives' Perceptions of HR Effectiveness: Services, Roles, and Contributions. Human Resource Management, 40, 111-123.

Yeandle, S., Crompton, R., Wigfield, A. and Dennet, J., 2002. Employed careers and family friendly employment policies. London: Joseph Rowntree Foundation Policy Press. 